
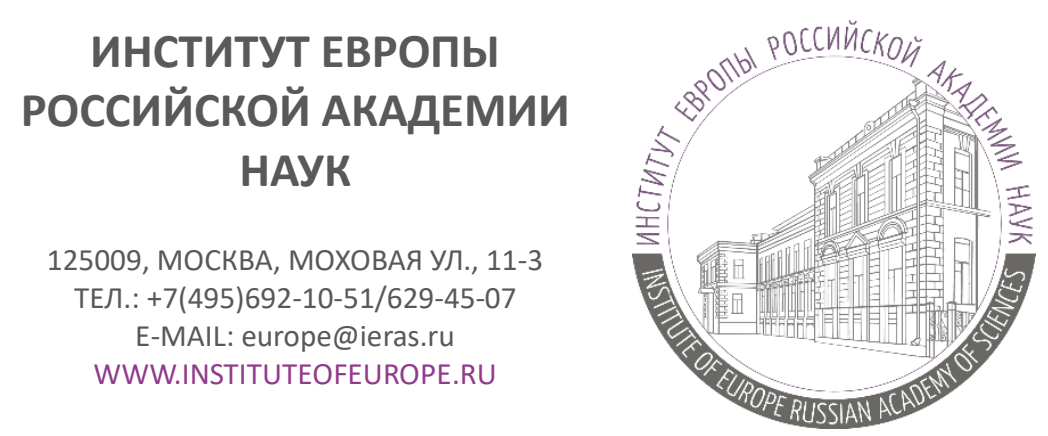

INSTITUTE OF EUROPE RUSSIAN ACADEMY OF SCIENCES

125009, MOSCOW, MOKHOVAYA STR., 11-3

TEL.: +7(495)692-10-51/629-45-07

E-MAIL: europe-ins@mail.ru WWW.INSTITUTEOFEUROPE.RU

Серия «Аналитические записки Института Европы РАН»

№47, 2020 (№230)

\title{
Первый социально ориентированный бюджет левой коалиции в Испании
}

\section{Владимир Леонидович Верников}

руководитель Центра иберийских исследований, старший научный сотрудник Отдела страновых исследований Института Европы РАН

\begin{abstract}
Аннотация. Записка посвящена принятому Конгрессом депутатов и утвержденному в декабре 2020 года Сенатом государственному бюджету Испании на 2021 год. Это первыий за постфранкистский период сочиально ориентированный документ первого левого коалиционного правительства ИСРП и партии «Подемос» («Mы можем!»). Автор анализирует сложный проиесс переговоров, содержание основных расходных статей и перспективы реализации нового бюджета.
\end{abstract}

Ключевые слова Бюджет, соииалисты, партия «Подемос», Народная партия, каталонские националисты, Левые республиканщь Каталонии, партия Сьюдаданос («Граждане»).

Испания вступает в 2021 год с актуальным государственным бюджетом. Два с половиной года до этого, хотя у власти и находились социалисты, страна жила по бюджетному плану правого правительства М. Рахоя, ушедшего из-за вотума недоверия. Ситуация объясняется просто: дважды П. Санчес терпел поражение при голосовании вотума доверия, не получив поддержки от своего партнёра по правительственной коалиции «Подемос», после чего неизбежно следовали новые парламентские выборы.

DOI: http://doi.org/10.15211/analytics472020 
До подготовки бюджета и его утверждения дело не доходило - не хватало времени.

На этот раз ситуация для первого в истории испанской политической системы левого коалиционного правительства социалистов и партии «Подемос» сложилась удачно. В начале декабря 2020 года Конгресс депутатов (нижняя палата парламента) абсолютным большинством голосов (188, при необходимых 176) принял бюджет без серьезных поправок. А в последнюю неделю декабря его утвердил Сенат - тоже абсолютным большинством. Никто не сомневался, что так и будет. Но между голосованиями потребовались три недели на изучение 4 тысяч поправок, внесенных правой Народной партией, ультраконсервативной Vox («Голос») и примкнувшей к ним «Сьюдаданос» («Граждане») (позиционирует себя как центристская партия после недавней смены руководства и идеологии) и рядом мелких региональных объединений.

Вся эта лавина поправок была нацелена на то, чтобы Сенат вернул проект бюджета для доработки в Конгресс депутатов в канун нового года, когда депутаты уйдут на каникулы. А уже к январю могли подоспеть события, способные вызвать открытое недовольство Левых республиканцев Каталонии (ЛРК) и баскских националистов, которые при голосовании могли передумать и не поддержать правительство П. Санчеса. Речь идет об их давнем требовании к властям помиловать осужденных ранее руководителей антигосударственного заговора о независимости Каталонии, находившемся на рассмотрении Верховного суда, который, как и следовало ожидать, примерно в те же дни вынес отрицательное решение.

Но сенатское большинство соцпартии разгадало маневр оппозиции и отвергло без обсуждения все поправки до единой. Это вызвало гневную реакцию находившихся в зале заседаний представителей правых, назвавших себя «невольными статистами на празднике узурпаторов парламентской демократии». «Очень печально, что готовишь свои инициативы для обсуждения, а в итоге становишься участником спектакля» ${ }^{1},-$ сокрушался сенатор Фабиан Чинеа. Но это было не более чем размахиванием кулаками после драки. А саму драку, точнее, баталии в нижней палате парламента, правые проиграли вчистую, позволив коалиционному правительству заручиться поддержкой даже тех партий, на которые оно не рассчитывало.

Глава кабинета П. Санчес вновь оказался хорошим тактиком, который в долгих и трудных переговорах добивался поддержки проекта бюджета даже со стороны «Граждан», всегда выступавших с резкой критикой правительства социалистов. Можно предположить, что таким образом он хотел в будущем снизить зависимость от лидера «Подемос» П. Иглесиаса, выдвигающего порой ультралевые и неприемлемые для соцпартии экономические предложения. А также на случай, если ЛРК будут требовать антиконституционных уступок накануне парламентских выборов в Каталонии. Не получив их, чтобы «не терять лицо» перед своими сторонниками, они в последнюю минуту могли бы отказаться от поддержки бюджета, что было бы равносильно голосованию вотума доверия коалиционному правительству. В этой ситуации неожиданно возникла политическая конкуренция между главой правительства и его

\footnotetext{
${ }^{1}$ El Pais.22.12.2020. El Gobierno saca adelante los Presupuestos en tiempo record
} 
вторым заместителем (П. Иглесиасом) за влияние на те партии, поддержку которых хотел получить П. Санчес.

Лидер «Подемос» был категорически против флирта с «Гражданами», идеологически близкими к правым. Он подозревал их в двойной игре при утверждении социально ориентированного бюджета и настаивал на поиске компромисса с ЛРК и левыми националистами Страны басков, Галисии и региональными депутатами от Арагона, Теруэля и Кантабрии. Он лично вел с ними переговоры, преодолевая скепсис коллег по коалиции и многих политических обозревателей. Не известны использованные им аргументы и данные обещания, но важен результат: все подписали соглашение о поддержке бюджета и проголосовали за него.

«Сьюдаданос» осталась вне игры и поддержала правую оппозицию. Но не обида на П. Санчеса двигала ею, а многолетнее неприятие самого факта участия П. Иглесиаса в правительстве и влияния «Подемос» на его решения в экономической и социальной областях. Это влияние и настойчивость ее лидера, как отмечают некоторые СМИ, раздражает не только главу правительства, который время от времени аккуратно пытается поставить своего заместителя на место, но и ближайших соратников по партии и кабинету, открыто заявляющих о том, что «Подемос» набирает очки в общественном мнении за счет «мягкости П. Санчеса».

На наш взгляд, прав известный испанский политолог Хуан Родригес Теруэль, считающий, что причина совсем в другом: «Лидер «Подемос» отвоевал себе роль собирателя левых, пусть даже националистических партий, добиваясь большинства в поддержке коалиционного правительства. Такого давно не наблюдалось во фрагментированном Конгрессе депутатов... Для партии он выжал максимум из своего присутствия в правительстве, но именно П. Иглесиас гарантирует Педро Санчесу поддержку трех или четырех групп, которую социалисты не имели бы без него» ${ }^{2}$. Такая политика вызывает ярость правой оппозиции, обвиняющей обоих лидеров в неконституционных уступках националистическим партиям ради своего выживания, что грозит привести к развалу единого государства.

Но это - фантомные страхи без аргументов и доказательств. Более правдоподобными выглядят суждения ряда обозревателей о том, что П. Иглесиас при определенных обстоятельствах рискнет прибегнуть к шантажу, «держа в рукаве» немногочисленные националистические формирования, которые обязаны ему своим нынешним положением арбитров при голосовании в парламенте. Поводом могут стать частые разногласия с П. Санчесом по вопросам экономической политики: несколько подобных эпизодов имели место даже при обсуждении уже согласованного в правительстве бюджета.

С другой стороны, усиление веса националистических партий грозит интересам «Подемос» на выборах в Каталонии и Стране басков - ведь борьба идет на одном электоральном поле за левого избирателя. Но существуют и немалые риски единству внутри этой партии, от которой уже откололись несколько ее региональных попутчиков,

\footnotetext{
${ }^{2}$ El Pais.07.12.2020. El riesgo del exito de Iglesias
} 
несогласных с каудилистскими амбициями П. Иглесиаса. «Подемос», с момента создания прокламировавшая себя массовой политической партией, на практике превратилась в «партию одного человека». И возросшая роль ее лидера в правительстве может иметь негативный эффект в будущем, когда нужно будет искать поддержку единомышленников.

До этого, правда, еще далеко. После утверждения бюджета парламентом у правительства впереди три с половиной года спокойной, но тяжелой работы. Принятый документ испанские СМИ называют экспансивным: за счет увеличения социальных расходов и изменения модели промышленного производства он может позволить стране выйти из кризиса, вызванного пандемией коронавируса. Поражают цифры расходов, ничего подобного не было за последние 30 лет: почти 240 млрд евро, включая средства из фондов Евросоюза (9 млрд на социальные нужды и 25 млрд на сокращение безработицы).

Одной из своих важнейших задач правительство видит изменение модели народного хозяйства. Сократив зависимость от туризма, энергоносителей и сервисных услуг, оно стремится сделать национальную экономику современной и конкурентоспособной, цифровой и инновационной. Для достижения этой цели выделено свыше 12 млрд, еще 11,5 млрд - на связанную с ней инфраструктурную реформу для «сшивания» территорий. Не забыты и возобновляемые источники энергии, и увеличение КПД производителей электричества, и модернизация машинного парка предприятий обрабатывающей промышленности (свыше 11 млрд).

Значительно (более 163 млрд) вырастут расходы на пенсионное обеспечение. Пенсионный фонд, испытывавший в последние десятилетия дефицит средств, впервые станет устойчивым и менее зависимым от налоговых колебаний. Вырастут инвестиции в человеческий капитал - школьное и среднее техническое образование, университеты (почти 5 млрд), а также в здравоохранение (свыше 5 млрд) и культуру (свыше 1 млрд).

Закономерен вопрос об источниках финансирования этих гигантских расходов. Вопервых, это планируемые налоговые и иные поступления в размере 222,1 млрд евро. Благодаря ожидаемому восстановлению экономики, это на 28,8\% больше, чем годом ранее. Но эксперты считают такой прогноз правительства слишком оптимистичным. Во-вторых, предусмотрен рост дефицита бюджета на 7,7\%. Это противоречит требованиям ЕС, но в нынешних условиях данное обстоятельство уже не сдерживает правительство П. Санчеса ${ }^{4}$. Также не известно, включает ли в себя этот рост уже израсходованные в 2020 году десятки миллиардов евро на субсидии малоимущим и прямую поддержку бизнеса, пострадавшего от пандемии. В-третьих, основная надежда власти в исполнении бюджета - это средства от ЕЦБ.

Прогнозы - рискованное занятие, тем более при нестабильной экономике стран ЕС, выступающих главными внешнеэкономическими партнерами Испании. В ЕС в 2020 году прогнозируется спад экономической активности на $11,5 \%$, а прогноз роста ВВП в

\footnotetext{
${ }^{4}$ Bсе приведенные выше цифры бюджетных расходов: EL Pais. 27.10.2020. Las principales lineas de los Presupuestos de 2021
} 
2021 году снижен с 6,1 до 4,2\%. Ожидается, что объём производства не достигнет доковидного уровня даже в 2022 году. Еврокомиссия надеется на позитивные эффекты утверждённого в середине декабря семилетнего бюджета ЕС в 1,8 трлн евро, включающего внебюджетный фонд «План следующего поколения» - 750 млрд на восстановление экономик стран, пострадавших от пандемии.

Испания рассчитывает на значительные суммы из этого фонда ${ }^{6}$, хотя сложно назвать срок, когда они поступят в её казну. В утвержденном госбюджете на 2021 год они указаны отдельно. Одновременно создан правительственный фонд по их эффективному использованию, и определены конкретные инвестиционные «точки». Пока нет ответа на вопрос, сумеет ли испанская экономика переварить эти средства. Вторая волна коронавируса, захлестнувшая страну и оказавшаяся намного сильнее первой, к концу года принесла еще больший спад экономической активности, в особенности в сферах туризма, сервиса, малого и среднего бизнеса. Это неизбежно потребует от правительства корректировки уже утверждённых планов и расходов. Иными словами, неизбежно латание бюджета, в ходе которого важно сохранить заложенную в него нынешними лидерами идеологию социально ориентированного антикризисного развития.

\section{Выводы}

Разработка левой коалицией социально ориентированного бюджета была ожидаема. С самого начала обсуждения в парламенте его проект вызвал противодействие правых и каталонских националистических партий. Они грозили правительству в условиях тяжелой экономической ситуации, вызванной пандемией, полностью отвергнуть бюджет как противоречащий национальным интересам. Главе кабинета П. Санчесу и его основному партнеру второму вице-премьеру П. Иглесиасу пришлось пройти тернистый путь переговоров с представленными в Конгрессе депутатов партиями, чтобы заручиться их поддержкой при голосовании важнейшего для страны документа. С этой точки зрения, принятие бюджета - безусловная победа первого в истории Испании левого коалиционного правительства.

В создавшейся экономической ситуации, которая с большой долей вероятности будет ухудшаться, исполнить бюджет будет сложно. Правительству предстоит доказать на практике свою эффективность в решении назревших экономических и социальных проблем. Другой альтернативы у него нет. В преддверии парламентских выборов в 2021 году в нескольких национальных регионах обеим партиям правящей коалиции важно не растерять авторитет. От успеха или неуспеха экономической политики правительства во многом зависит и политическая стабильность в тех национальных автономиях, где сильны сепаратистские настроения.

Дата выпуска: 29 декабря 2020 года.

\footnotetext{
${ }^{6}$ Подробнее см.: Верников В.Л. Коронавирус в Испании туристами не испугаешь. Аналитическая записка №30, 2020 (№213). URL: https://www.instituteofeurope.ru/images/uploads/analitika/2020/an213.pdf
} 


\title{
Series of articles in journal «Analytical papers of the Institute of Europe RAS»
}

№47, 2020 (№230)

\section{The first socially oriented budget of the left coalition in Spain}

\begin{abstract}
The article is dedicated to the state budget of Spain for 2021 adopted by the Congress of Deputies and approved by the Senate in December 2020. It is the first socially oriented document of the first leftist coalition government of PSRP and Podemos party in post-Franco period. The author analyzes the complex process of negotiations, major items of budget expenditures and prospects for its implementation.
\end{abstract}

Keywords: Budget, Socialists, Podemos Party, People's Party, Catalan Nationalists, Left Republicans of Catalonia, Ciudadanos Party.

DOI: http://doi.org/10.15211/analytics 472020

http://www.zapiski-ieran.ru

Release date: December 29, 2020. 